\title{
Administrative Legislation for Tax Payoff by Combining Tax Payments, Land Allotment, Service Concession under Humanitarian Approach
}

\author{
Basilios Kanavas ${ }^{1}$, Athanasios Zisopoulos, ${ }^{2, *}$ \\ ${ }^{1}$ Law Faculty, Aristoteles University of Thessaloniki, Thessaloniki, Greece \\ ${ }^{2}$ Applied Mathematics, Faculty of Mathematics and Informatics, University of Sofia “St. Kliment Ohridski”, Sofia Bulgaria \\ *Corresponding author: zisopoulos.athanasios.dim@gmail.com
}

\begin{abstract}
We introduce the concept for an intelligent settlement to collect state taxes as a semi-automatic procedure that meets three major guidelines where all parties are satisfied; all taxes and penalties will be paid, state frozen property reallocation and finally the creation of a low profit survival job. Such a settlement is assembled primarily by state resources re-allocation to be evaluated. The list includes Land allotment, Service Concession, patent use and others. After the initial approach we use mathematical modelling with financial time series for all subsequent model payments. In our case study we assumed that the tax payer has a debt of 100,000 $€$ and an equal bank amount. His obligation to pay the debt is not eligible since he cannot survive thereafter. The following option is not to pay and to live underground for ten years without taxes, VAT and son on. We introduced a third solution which is to intergrade the payment with a land allotment. With this option everybody lives happily forever while the government will collect a total of 300,000 €. This profit needs large scale arrangements like an expert system to find state resources, a special "humanitarian taxes" Parliament session, Frozen property request description along with various Future developments for intelligent tax payments settlement.
\end{abstract}

Keywords: poverty management, intelligent payments, tax collection, land allotment, service concession, humanitarian investments, tax law, financial time series

Cite This Article: Basilios Kanavas, and Athanasios Zisopoulos, "Administrative Legislation for Tax Payoff by Combining Tax Payments, Land Allotment, Service Concession under Humanitarian Approach.” Journal of Finance and Accounting, vol. 5, no. 1 (2017): 6-13. doi: 10.12691/jfa-5-1-2.

\section{Introduction}

Historically taxes arisen from the dawn of human race. From that times they have universal characteristics reflecting the worst mankind greediness, selfishness, disordering and eudemonism. Tax collection legislation is written in history, Bible and cinematography. In our globalization times tax collection evolved in an impossible mission due to offshore banking, invoices and investments triangles and unlimited tax avoidance tricks on the edge of legality. We study for years' money laundering antisocial policies like Bank capture, Black salaries, Bulk cash smuggling, Cash-intensive businesses, Casinos, Fictional loans, Real estate, Round-tripping, Shell companies and trusts, Structuring, Trade-based laundering etc $[14,18]$. However, these and a lot more represent the dark side of the tax collection system. In order to fight all these, we become every day, little by little, exactly like them. Evil feeds evil and war brings war.

Another problem is the survival odyssey that a lot of previous rich people they live. In Greece and all around the world a lot of people live according to Bible and Gospel early stages. They do live in the seven years of Josef. We read from the GENESIS:
"5Now Joseph said to Pharaoh, "Pharaoh's dreams are one and the same; God has told to Pharaoh what He is about to do. 26"The seven good cows are seven years; and the seven good ears are seven years; the dreams are one and the same. 27"The seven lean and ugly cows that came up after them are seven years, and the seven thin ears scorched by the east wind will be seven years of famine."

Also we study from the Gospel the prodigal son parabola that eliminated all his property and had nothing even to eat.

It happened twice in Bible, it happens once more today. Wealthy citizens neglected to pay their taxes. They postponed happily such low level tasks where there was not heroism at all. Unfortunately, today all of them face humanitarian crisis. They do not pay taxes; they have nothing even to survive. The state must find a way to of Humanitarian Funding the severe problem. Then through real Humanitarian Funding bond actions it could collect the invested money back [16].

For all these reasons Positive thinking brought us to a number of actions, that civilized Public administration could endorse to collect delayed taxes. [3,9]. These proposals equal balance between:

- Imperative strong tax collection action and creative cooperation between the IRS and tax payers.

- State does not reward and funds the prodigal son but it needs the tax money for the poor. 
- State legislation has to be applied to all citizens but not to departed bodies.

On the direction of mutual interest of the state and the tax payer, today we analyze and propose a simple action with a specific timeline:

- Initially the taxpayer recognizes its debt and its poverty.

- He suggests to pay the debt partially and

- To acquire a profitable unused or frozen state property.

- In a two-year short period of time the state collects all his taxes plus a $20 \%$ profit.

- After the two years the citizen has a new profitable job.

\section{Land Allotment-Service Concession}

The Hellenic public division holds the most valuable properties. Generally, this property does not offer anything to GNP. One of the reason of the economic crisis is exactly this inability to invest on these frozen assets $[2,12]$.

Frozen assets reassignment legislation is very limited in Greece and European Union [11,15].

\subsection{Land Allotment}

For the needs of our research we analyzed West Macedonia Region and we found a few indicative such resources. They all represent serious investments eligible for humanitarian funding. The land allotment described below must has more limited duration than a similar action for business allocation because it concerns temporary humanitarian arrangement.

Abandoned houses and cars; an action that is under implementation six years now in Greece.

Abandoned land on the borderlines of Greece; This could a valuable business opportunity because abandoned land is also idyllically landscapes very rare and expensive to find.

Sidewalks interstate highways and intersection road area; where pellet growing and harvest is possible. We have contract for a similar patent in order to gain preferential status to obtain the right.

Several thousand GWh of thermal energy from the local PPC Public Power Corporation; The energy we take limits the cooling water consumption for PPC. The thermal energy drawing rights will be given to various citizens. These thermal power holders will create a greenhouse, an ideal humanitarian funding case study.

Grazing land without water wells or reservoirs; $50 \%$ of West Macedonia is such a land. There is grass fur the bovine installation but there is not water for the cow, since every cow needs $50 \mathrm{kgr}$ per day a whole ton per day for the herd. The secret here is the rain-harvest mechanism on the ECO- MOBIFARM patent, that offers unlimited water from a single rainfall [24].

Total desert land use for 30 years; With a similar patent a farmer could produce electricity, feed thousands of ships and delivers the land as well established grassland.

\subsection{New Service Concession}

A business opportunity based on service concession could also described as a sublicensing of existing services but for the purpose of our research we focus to creative out of zero new opportunities [7]. The reason is that political system is not ready to abolish its dominant position to decide every aspect of life and business [13]. New services for West Macedonia could be:

Prisoner or refugee rehabilitation in village families; Despite the Legislation and Media reference two families in a village could survive out of the hospitality of one single prisoner. In Greece the prisoner costs over 1000 Euros per month to the country's rehabilitation system. A similar cost Hellenic society faces for refugee's care.

The right-license for additional authorization to verify Biological Productions; preferential status here is gained through a related patent application to be filed in the next months.

The right to establish a heavy machine carwash in local PPC mines.

The right-license to establish a no-vehicle area in a seaside resort; The relevant patent "Digital saddle for semi-automatic control of service animals and partially reinstating the animal-drawn economy" give us the business opportunity and preferential status necessary to start the business [23,24].

The right-license to fight coastial forest fires; The related patent is "Airborne pipeline docked to an earth reservoir to deliver water over long distance for aerial firefighting and irrigation” [21].

\subsection{Expert System to Find State Resources}

All the above are everlasting citizens' requests that we organized to enter the $22^{\text {nd }}$ century.

The expert system is fed with data like:

- Questionnaire

- Site analyze robot

- National account sub-expert

- Poverty Management guidelines

- Basil III collaterals.

\subsection{Intelligent Settlement}

The concept for an intelligent settlement is to find a semi -automatic procedure which meets a few guidelines, $[1,4]$ :

- All the accumulated taxes and penalties will be paid;

- The state gives frozen properties to the citizen.

- The citizen finds a low profit survival job.

- All parties are satisfied.

Such a settlement is not easy to be assembled primarily because there are millions of non-linear interoperated options to be evaluated. The paper gives an initial estimation of the options and their range to be considered about.

\section{Humanitarian Financial Time Series Example}

A macroscopic simplified tax accounting diary will simplify the mutual profit for both State and taxed object. The initial hypothesis is straightforward and simply. The taxpayer has cash money 100,000 Euro while there is an 
equal taxes acclaim of $100,000 €$. The loyalty citizen pays its debit and reaches disaster, since there is no way to survive without money and Job. If the Greek IRS attempts this action violates the Constitution. Hellenic constitution (article 22.4) where is denoted clearly:

"the state is obligated to find a profession to its citizens"

In order to avoid such a violation but altogether to finance basic state functions our micro-Humanitarian Funding opinion is dual:

- The State has to collect money.

- The tax payer has to survive, to continue life and tax payments.

We propose a settlement like this:

- The citizen pays his tax partially (60\% cash).

- The state transfers to him frozen property for 30 years or assigns him a profitable state service or function.

- The citizen retains a $10 \%$ of the cash as a working capital.

The simplified Accounting records have the year, the diary description and the amount. The formatting is exactly accounting where the credit is shown with red color.

From this cash flow sheet, we calculate two tables. The first is the calculation of the indirect taxes generated by the living cost of any citizen. According to this accounting calculation the specific low income is consumed all in survival primitive needs. These spending brings in tax and
VAT cash income that otherwise in the unemployment status would not exist $[17,19]$.

\subsection{Financial Time Series 1, Tax and VAT Collected}

\section{Matlab solution}

Taxdata $=$ [oldTAXpayments, newTAXVATpayment,workingcapital,generatedTAXVA $\mathrm{T}]$;

taxnames $=\{$ 'oldTAXpayments',

'newTAXVATpayment','workingcapital',

'generatedTAXVAT'\};

tax= fints(dates,taxdata, taxnames,0,'TAX payments'); chartfts(tax);

Where tables to formulate appropriate timeseries are:

- date : the associated date for every payment

- oldTAXpayments: payments to eliminate initial tax debt.

- NewTAXVATpayment: annual tax for the profession

- WorkingCapital

- Generated TAXVAT The secondary generated Tax and VAT

Negative values are necessary for the mathematical model to work right and they denote taxpayer outflow cash, that is tax payments.

Table 1. Time series of total state TAX-VAT

\begin{tabular}{|c|c|c|c|c|}
\hline dates & Old TAX payments & New TAX VAT payment & Working capital & Generated TAX VAT \\
\hline $01-01-16$ & 0 & 0 & 0 & 0 \\
\hline $31-01-16$ & -25000 & -360 & -1000 & -256 \\
\hline $01-03-16$ & -20000 & -360 & -1000 & -256 \\
\hline $31-03-16$ & 0 & -360 & -1000 & -256 \\
\hline $30-04-16$ & 0 & -360 & -1000 & -256 \\
\hline $30-05-16$ & -20000 & -360 & -500 & -256 \\
\hline $29-06-16$ & -25000 & -360 & -500 & -256 \\
\hline $29-07-16$ & 0 & -360 & -500 & -256 \\
\hline$\ldots$ & 0 & -360 & -500 & -256 \\
\hline $17-10-18$ & 0 & -360 & 0 & -256 \\
\hline $16-11-18$ & 0 & -360 & 0 & -256 \\
\hline $16-12-18$ & 0 & -360 & 0 & -256 \\
\hline
\end{tabular}

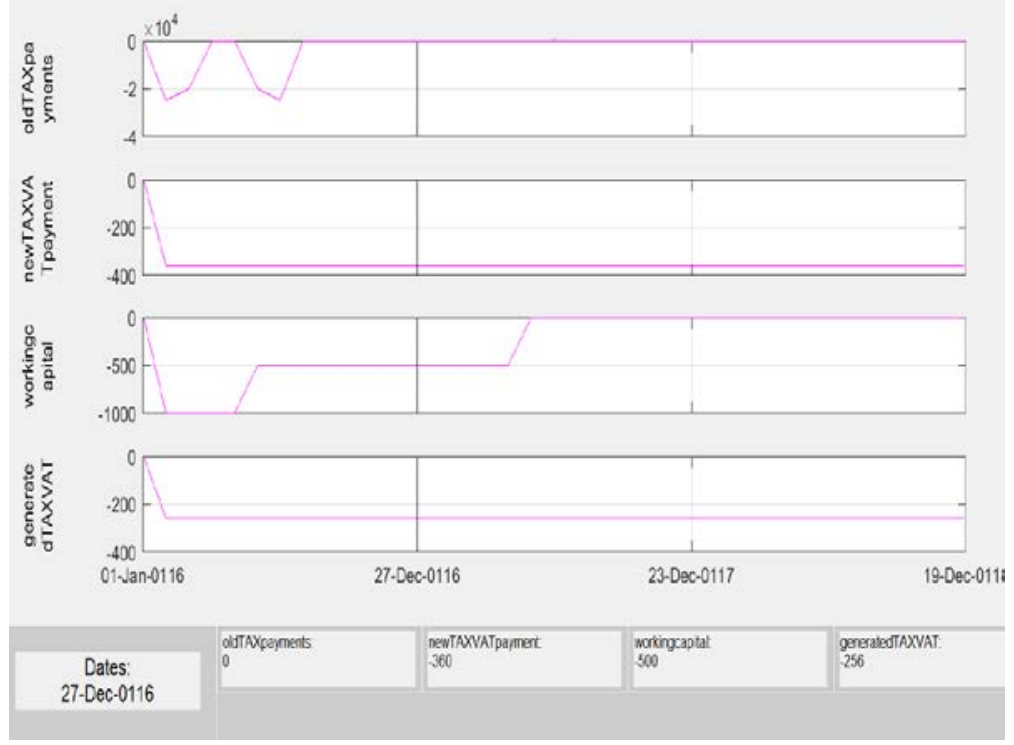

Figure 1. The four Tax instances 


\subsection{Financial Time Series 2, Income}

\section{Matlab solution}

incomedata $=$ [income , savings ];

incomename $=\{$ 'GROSS' 'bankSavings' $\}$;

in=fints(dates,incomedata,incomename, 0,'INCOME
FLOW');

chartfts(in);

The financial time series is constructed by the beneficiary income $1000 €$ per month, from which savings rang from the initial 100000 and thereafter 128 Euro cash deposit

Table 2. Financial Time series of beneficiary income and savings

\begin{tabular}{|c|c|c|}
\hline Dates & income & Savings \\
\hline 01-01-16 & 0 & 100000 \\
\hline $31-01-16$ & 1000 & 128 \\
\hline 01-03-16 & 1000 & 128 \\
\hline 31-03-16 & 1000 & 128 \\
\hline $30-04-16$ & 1000 & 128 \\
\hline $30-05-16$ & 1000 & 128 \\
\hline$\ldots$ & 1000 & 128 \\
\hline 20-01-18 & 1000 & 128 \\
\hline $19-02-18$ & 1000 & 128 \\
\hline 21-03-18 & 1000 & 128 \\
\hline 20-04-18 & 1000 & 128 \\
\hline $20-05-18$ & 1000 & 128 \\
\hline $19-06-18$ & 1000 & 128 \\
\hline $19-07-18$ & 1000 & 128 \\
\hline $18-08-18$ & 1000 & 128 \\
\hline $17-09-18$ & 1000 & 128 \\
\hline $17-10-18$ & 1000 & 128 \\
\hline $16-11-18$ & 1000 & 128 \\
\hline $16-12-18$ & 1000 & 128 \\
\hline
\end{tabular}

Interactive Chart: INCOME FLOW

File Edit View Insert Desktop Window Help Chart Tools

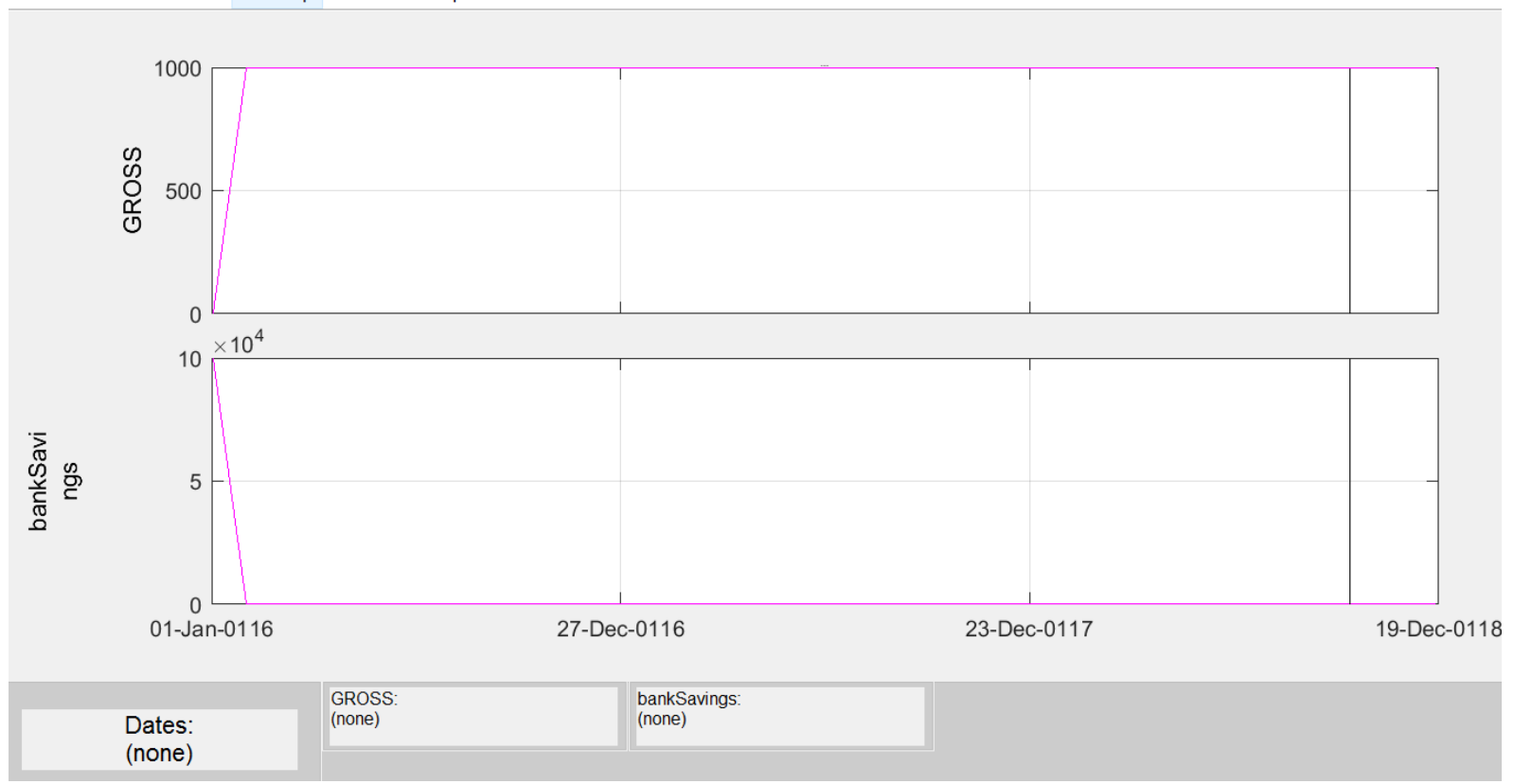

Figure 2. The income flow from taxpayer view 


\subsection{Financial Time Series 3 Accumulated STATE-BENEFICIARY savings}

\section{Matlab solution is}

accumulatedata =

[accumulateStateTAX,BeneficiaryBankAmount]; accumulatename $=\{$ 'StateTAX' , 'BankAmount' $\}$;

summary= fints(dates, accumulatedata, accumulatename,

0 , 'HumanitarianSummary');

chartfts (summary);

The final third financial time series is the Accumulate for the State and the citizen.

Table 3. Summary Time series

\begin{tabular}{|c|c|c|}
\hline Dates & Accumulate StateTAX & Beneficiary BankAmount \\
\hline 01-01-16 & 0 & 100000 \\
\hline 31-01-16 & -25616 & 74128 \\
\hline 01-03-16 & -46232 & 53256 \\
\hline 31-03-16 & -46848 & 52384 \\
\hline $30-04-16$ & -47464 & 51512 \\
\hline $30-05-16$ & -68080 & 31140 \\
\hline $29-06-16$ & -93696 & 5768 \\
\hline $29-07-16$ & -94312 & 5396 \\
\hline $28-08-16$ & -94928 & 5024 \\
\hline $27-09-16$ & -95544 & 4652 \\
\hline $27-10-16$ & -96160 & 4280 \\
\hline 26-11-16 & -96776 & 3908 \\
\hline $26-12-16$ & -97392 & 3536 \\
\hline $25-01-17$ & -98008 & 3164 \\
\hline $24-02-17$ & -98624 & 2792 \\
\hline $26-03-17$ & -99240 & 2420 \\
\hline $25-04-17$ & -99856 & 2048 \\
\hline $25-05-17$ & -100472 & 2176 \\
\hline $24-06-17$ & -101088 & 2304 \\
\hline 24-07-17 & -101704 & 2432 \\
\hline 23-08-17 & -102320 & 2560 \\
\hline $22-09-17$ & -102936 & 2688 \\
\hline $22-10-17$ & -103552 & 2816 \\
\hline $21-11-17$ & -104168 & 2944 \\
\hline $21-12-17$ & -104784 & 3072 \\
\hline 20-01-18 & -105400 & 3200 \\
\hline $19-02-18$ & -106016 & 3328 \\
\hline 21-03-18 & -106632 & 3456 \\
\hline $20-04-18$ & -107248 & 3584 \\
\hline $20-05-18$ & -107864 & 3712 \\
\hline $19-06-18$ & -108480 & 3840 \\
\hline $19-07-18$ & -109096 & 3968 \\
\hline $18-08-18$ & -109712 & 4096 \\
\hline $17-09-18$ & -110328 & 4224 \\
\hline $17-10-18$ & -110944 & 4352 \\
\hline $16-11-18$ & -111560 & 4480 \\
\hline $16-12-18$ & -112176 & 4608 \\
\hline
\end{tabular}




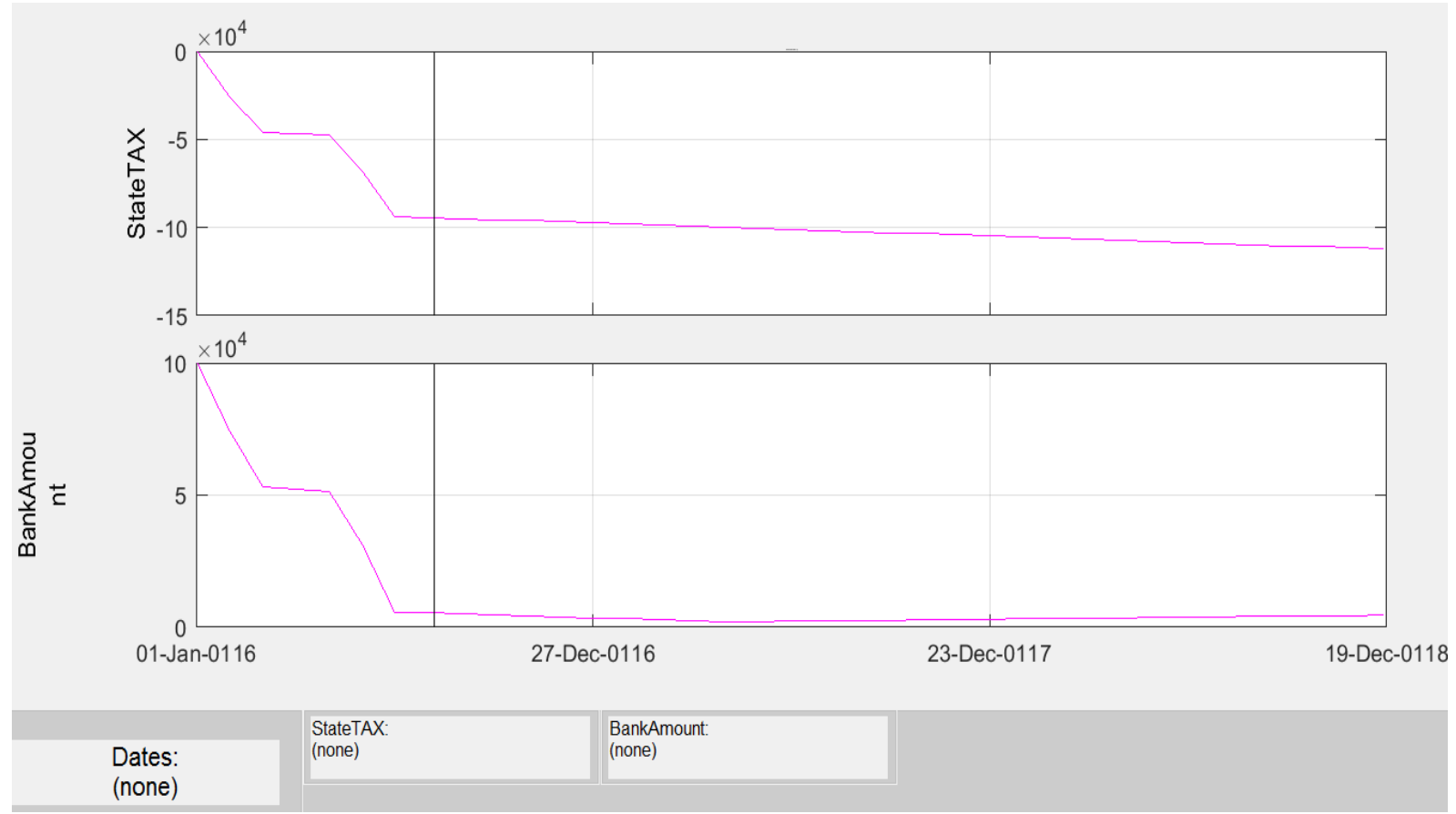

Figure 3. The methodology break-even point

As result the Government has three major achievements:

1. collected more money than any other arbitrage method

2. citizen lives on

3. and pays his taxes.

\subsection{Black Money Living}

The ten year projection clarifies the methodology proposed.

If the state IRS persists to collect the 100,000 Tax, the tax payer holds the money and enter black money living. The citizen lives for ten years but the government loses the 100000 fine and the additional TAX and VAT of 180000 , a total of 280 thousand just for being serious.

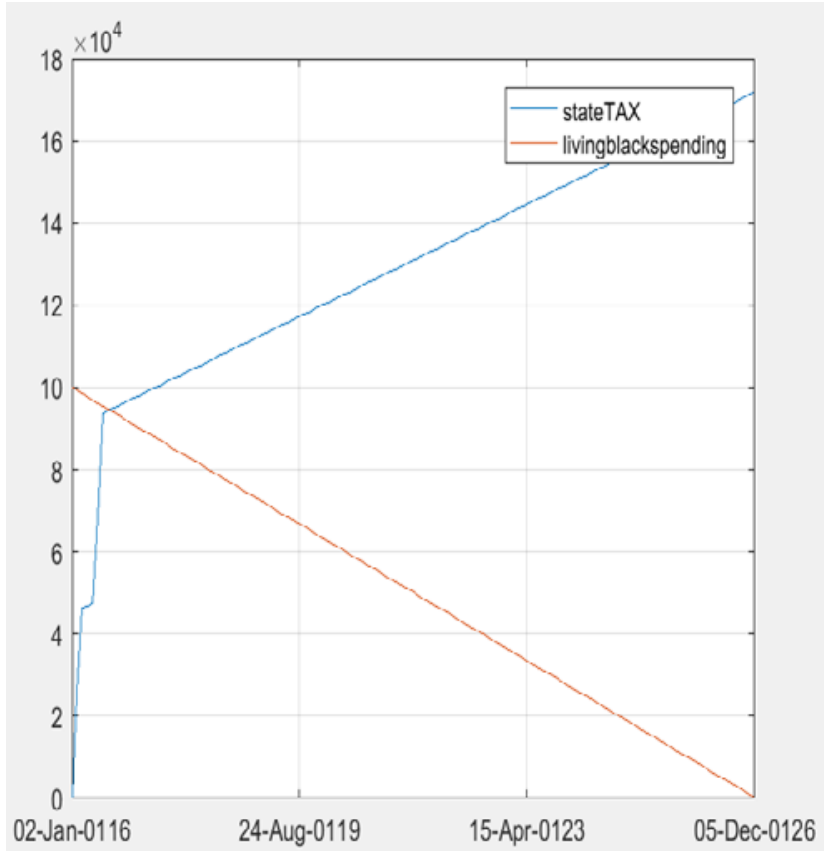

Figure 4. Ten years legitimate or black money living

\section{Special "humanitarian taxes" Parliament Session}

The humanitarian project that we suggested is already very complicated with unlimited options and funding calculations. A very useful action is to prepare carefully and most important legally the land allotment and service concession. There will be two parallel inspiration sources to locate a non-useful valuable asset or service.

Initially the Hellenic state seeks for frozen business opportunities. Municipalities could play and important role on this explanatory action, regional development agencies they function similar projects and universities promote entrepreneurship already for years. Our questioning and fear started already to the grasping bureaucracy nature. Public servants might want these new business for themselves or their political friends. Even worst is the situation where the public servant remembers a very well-known proverb in Greece ("let the ship of the neighbor die"). Unfortunately, they prefer to find an excuse in order not to conclude the allotment deal. We don't believe to them and their effective cooperation.

The second option to track a profitable opportunity is the delayed tax-payer itself. This cannot be done in a typical request to the state authorities, not even in a proposal for tax payoff to the local Tax agency. They cannot understand the chaotic interrelation of totally different options as described above. The tax payer must submit a digital form with all necessary data. Al the forms will be processed local and feed the proposal to the council of ministers.

There are unlimited legal problems to realize any simple humanitarian-taxpaying action. On the other hand the era of computer to law automatic legislation will be not implemented in the foreseen future. We strongly believe that the only solution is the Hellenic parliament after the opinion of the government. At a first reading it seems like to legalize the bribery and bring it in the higher 
possibly level; the democracy temple. It is not that bad, Maslow hierarch of needs advices us to face the humanitarian necessity and temporarily bypass any navel-gazing. After all, cronyism is another aspect of real life, an extreme democracy tool, just a step in front of the disaster.

The implementation steps are complicated.

Step 1, Form fill: After the tax debt finalization, the citizen through his lawyer and accountant fills in a detailed form to settle the debt.

In case he finds a desired allotment or service capable to fulfill his survival needs he proceeds to the next step 3 .

Step 2, Frozen property request description: with the help of his staff or specialized public servants he describes in legal terms the desired land allotment or concise service to be acquired. The proposal carries along a preferential patent type of protection in order no to be distributed around to everybody.

Step 3, Final arbitrage request: After business humanitarian plan has been finalized he finalizes the request to be protected by the law, giving all necessary details.

Step 4, Arbitrage preparations: The IRS distributes the request to appropriate ministries and municipalities.

Step 5, Parliament legislative session: The Tax collection Ministry once a month sends the necessary legislation amending to the parliament.

Step 6, payments and beginning of new life: All contract and pending payments are arranged to start the profitable new life without debts and with phosphorus income.

Table 4. settlement six steps

\begin{tabular}{|l|c|c|c|}
\hline Task Name & Duration & Start & Finish \\
\hline Step 1, Form fill & 5 days & Oct 19 '16 & Oct 25 '16 \\
\hline $\begin{array}{l}\text { Step2, Frozen property } \\
\text { request description }\end{array}$ & 10 days & Oct 26 '16 & Nov 8 '16 \\
\hline $\begin{array}{l}\text { Step 3, Final arbitrage } \\
\text { request }\end{array}$ & 30 days & Nov 9 '16 & Dec 20 '16 \\
\hline $\begin{array}{l}\text { Step 4, Arbitrage } \\
\text { preparations }\end{array}$ & 30 days & Dec 21 '16 & Jan 31 '17 \\
\hline $\begin{array}{l}\text { Step 5, Parliament legislative } \\
\text { session }\end{array}$ & 60 days & Feb 1 '17 & Apr 25 '17 \\
\hline $\begin{array}{l}\text { Step 6, payments and } \\
\text { beginning of new life }\end{array}$ & 10 days & Apr 26 '17 & May 9 '17 \\
\hline
\end{tabular}

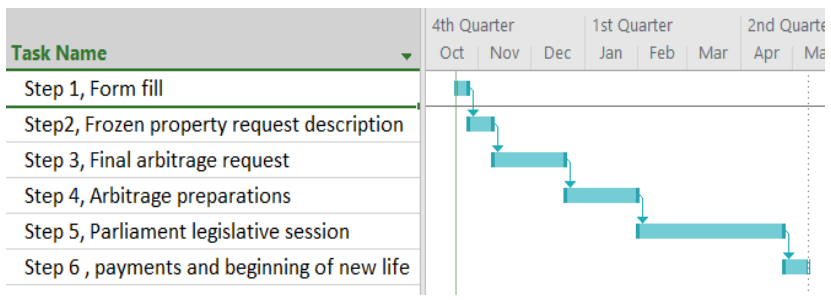

Figure 5. consecutive steps Gant chart

\section{Conclusion and Recommendation for Humanitarian Funding}

In our case study we assumed that the taxpayer has some money and humanitarian problems at the lower survival level. The proposed methodology applies to all various types of debts.
All the assumptions we made for this proposal are true and safe. However real life is more complicated and could outperform these rules in almost all basic and implementation concepts. Due to such a complexity severe auditing shown a few drawbacks of our methodology.

\subsection{Step 2, Frozen Property Request Description}

During step 2 the poor citizen finds a small out rated business potential and proposes to the public administration, demanding having exclusive rights on the idea.

Powerful companies interpret the above phrase according to their own profit:

The poor citizen finds a small out rated huge business potential and proposes bribes the public administration, demanding exclusive rights on the idea whole industry.

Through such a intrigue a health and not humanitarian necessity subject company could acquire valuable asset of the thermal energy of a power plant or the entire grazing area of mount Pindos.

Auditing arrangements here are:

- Similar allotments and service concession services request are suspicious.

- A legislative action is possible needed.

\subsection{Commodification of Humanitarian Actions}

Another option to freely organize the humanitarian actions is to commodify allotments and concessions in a more organized way. Commodification here also needs severe legislative action and includes:

- Homogenization of similar requests.

- Valutation of similar cases and requests.

- Transfer all responsibility and transactions in a private company.

- Serious mathematical work for valutation and auditing.

\subsection{The Debt as a Valuable Asset}

In international accounting there was cases where companies with significant high tax debts were more valuable than clear taxes companies. That was because the bankrupted companies have to pay in the forthcoming years more than $20 \%$ less taxes. Large agencies could buy poor citizen debts and use it as a tool to create new markets.

Far or less this is happening in the so called "vulture" funds but with money only.

Since we cannot prohibit the citizen to sell its debt or to authorize a person to negotiate with the State authorities, it is very difficult to eliminate such behavior $[8,10]$.

\subsection{Future Developments}

We currently work for the future steps of our suggested policy:

- An expert system to track land allotments and service concessions opportunities. 
- A severe legislative initiative to prepare the exact law for the tax-humanitarian combined action.

- A full feature big scale actual Humanitarian Funding (in his originated bond market nature) at a national level for additional money and management resources.

- A NLP (Neuro Linguistics Programming) option to radically promote the humanitarian-legislative nature of our proposal.

- A mathematical model to incorporate all various aspects of this preliminary research into a concise mathematical model.

There is also need to support the IRS Computer Forms realization, taxpayer file preparation and other similar actions. All these are not our obligations but trivial public administration tasks that they will follow methodology adoption.

\section{References}

[1] Andresen, T., \& Parenteau, R. W. (2015). A program proposal for creating a complementary currency in Greece. real-world economics review, 71, 2-10.

[2] Brown, Alexander L., and Joanna N. Lahey. Small victories: creating intrinsic motivation in savings and debt reduction. No. w20125. National Bureau of Economic Research, 2014.

[3] Burford, Alison. Land and labor in the Greek world. Johns Hopkins University Press, 1993.

[4] Cretzler, D. J. (1997). U.S. Patent No. 5,644,724. Washington, DC: U.S. Patent and Trademark Office.

[5] Mathematic and Algorithmic Failure Meet Misinterpretation and Inefficiency in Integrated Systems for FOREX, CFD, Taxis-Net and E-Banking, George Gerakis1, Athanasios Zisopoulos, 9th International Conference "New Horizons in Industry, Business and Education" (NHIBE 2015) 27-29 August 2015 Skiathos Island, Greece.

[6] George Gerakis, Razis Dimitrios,Athanasios Zisopoulos, "NICODIMUS, a forensic device to support Avocate and Judger public function and office”, International Symposium on Ambient Intelligence and Embedded Systems, 22 - 24 September, 2016, Heraklion, Crete, Greece.

[7] Giornetti, A. (2014). Ifric 12 service concession arrangements and market disclosure quality. Investigation amongst European listed companies in the more extensive scenario of accounting standardisation: Investigation amongst European listed companies in the more extensive scenario of accounting standardisation. Franco Angeli.

[8] Gorton, G., Lewellen, S., \& Metrick, A. (2012). The safe-asset share. The American Economic Review, 102(3), 101-106.
[9] Graeber, David. Debt-Updated and Expanded: The First 5,000 Years. Melville House, 2014.

[10] Graham, J. R. (2000). How big are the tax benefits of debt?. The Journal of Finance, 55(5), 1901-1941.

[11] Haddow, G., Bullock, J., \& Coppola, D. P. (2013). Introduction to emergency management. Butterworth-Heinemann.

[12] Huls, Nick. "A next step in debt enforcement: the merger of debt help and debt collection." Journal of consumer policy 35.4 (2012): 497-508.

[13] Pinheiro, A. C., \& Schneider, B. R. (2017). Markets and Hierarchies in Public Services: Incentives, Institutions, and Politics. In Improving Access and Quality of Public Services in Latin America (pp. 37-65). Palgrave Macmillan US.

[14] Ryder, N. (2015). Money laundering and the United Kingdom: A haven for dirty money and an endless cycle? A critical reflection on the United Kingdom's anti-money laundering policies.

[15] Sazak, S. C. (2015). An argument for using frozen assets for humanitarian assistance in refugee situations 1 . Journal of International Affairs, 68(2), 305.

[16] Tanabe, M., Schaus, K., Rastogi, S., Krause, S. K., \& Patel, P. (2015). Tracking humanitarian funding for reproductive health: a systematic analysis of health and protection proposals from 20022013. Conflict and health, 9(1), 1.

[17] Taylor, S. J. (2007). Modelling financial time series.

[18] Villa, E., Loayza, N., \& Misas, M. A. (2016). Illicit activity and money laundering from an economic growth perspective: a model and an application to Colombia. World Bank Policy Research Working Paper, (7578).

[19] Wallich, H. C., \& Weintraub, S. (1971). A tax-based incomes policy. journal of Economic Issues, 5(2), 1-19.

[20] Zisopoulos Dimitrios, Zero operating eco footprint integrated mobile animal farm, EU patent, 20120100057, Athens, 2012.

[21] Zisopoulos Athanasios, Airborne pipeline docked to an earth reservoir to deliver water over long distance for aerial firefighting and irrigation, EU patent, 20160100455, Athens, 2016.

[22] Zisopoulos Athanasios, Digital saddle for semi-automatic control of service animals and partially reinstating the animal-drawn economy, EU patent, 20160100223, Athens, 2016.

[23] Zisopoulos Athanasios, General Purpose Recording Device To Embed Forensics Accepted Digital Certificates To The Internet Distributed Art, Communication And Politics Multimedia Products, EU patent, 20160100277, Athens, 2016.

[24] Zisopoulos Athanasios, Gerakis George, DIGIGISAD: Digital saddle for semi-automatic control of service animals and partially reinstating the animal-drawn economy., 11th Annual MIBES International Conference, Heraklion, Crete, 22nd of June - 24th of June 2016.

[25] Zisopoulou Stefany, Gerakis George. 2-15, "MOBIFARM, Zero Operating Eco Footprint Integrated Mobile Animal Farm, Technology and Entrepreneurship", The 9th International conference on "New Horizons in Industry, Business and Education" Skiathos Island 27-29 August 2015. 